\title{
Balkan Corruption Perception: Impediments To Competitive Activity In Bosnia- Herzegovina, Croatia, FYROM, Serbia/Montenegro, And Slovenia
}

\author{
Frank H. Wadsworth, Ph.D., Indiana University Purdue University Columbus, USA \\ Jerry Wheat, Ph.D., Indiana University Purdue University Columbus, USA \\ Brenda Swartz, Ph.D., Indiana University Southeast, USA
}

\begin{abstract}
Corruption exists around the world in various forms. This paper examines the extent of political corruption in the countries that were formerly known as Yugoslavia. Data from the World Bank Institute and the European Bank for Reconstruction and Development Business Environment and Economic Performance Study (BEEPS) was used to examine the extent of corruption in these five regions from 2002 to 2005. Results show less corruption in Slovenia, Bosnia and Herzegovina, and Croatia than in FYROM (former Yugoslav Republic of Macedonia), Serbia, and Montenegro. Overall all countries appear to have less corruption in 2005 than in 2002.
\end{abstract}

Keywords: Corruption in Yugoslavia, Corruption in Former Yugoslav Republic of Macedonia; Balkan Corruption

\section{INTRODUCTION}

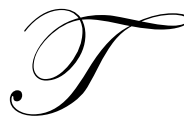

he Balkan Peninsula has a number of diverse populations which during the post-World War II period were unified as Yugoslavia under the leadership of Josip Broz Tito (1892-1980). During WWII Tito and partisan groups had shunned Stalin's assistance and without the Red Army's intervention routed the Germans from the Balkans. In the post WWII era Moscow exerted little influence over Yugoslavia. The country's form of socialism differed from the Soviet brand in that in Yugoslavia the means of production were owned by the state, but the state did pay attention to market forces in determining what to produce. The death of Tito with no strong successor and the demise of the Soviet Union and their termination of control in Eastern Europe gave rise to changes. Centuries' old culture groups long silenced under Tito began to re-assert themselves and at times have been contentious. Sequentially, over a decade territories that had been part of Yugoslavia declared themselves to be independent states. For four decades the area shared a common government; the recently emerging states exhibit differences often based on cultural ties quasi dormant for decades.

What had been the single country of Yugoslavia has become a handful of separate countries/regions each defining itself and struggling to increase its economic prosperity. In teasing out the differences country to country one can identify features that appear to be consistent with fostering an expanding economy. Also apparent are features that seem to inhibit growth and development and may be associated with the elusive "underground economy."

\section{LITERATURE REVIEW}

Political corruption occurs when government officials use their official powers for unlawful private gain. In some countries when business people or citizens desire services such as telephone, electricity, and water it is well known that unofficial payments are expected by government officials. Often in these countries salaries of public officials are meager and political corruption is considered the normal way to supplement government salaries. A 
lack of transparency, inconsistent norms, and certain practices that are legal in one country may be illegal in another country are examples of situations that support the occurrence of corruption. In some countries, government officials have broad or poorly defined powers, and distinguishing between activities that are legal and not legal can be difficult. Prior to 1996 the World Bank considered bribery to be an important component in the functioning of business and government. In 1996 James Wolfensohn (1996), president of the World Bank, declared that bribery was sand in the wheels of commerce and not the grease that made the wheels turn.

In 2006, Transparency International (2006) estimated that one single political corruption activity, bribery for government contracts, was estimated to cost about $\$ 400$ billion. According to Nichols (2000), the payment of bribes hurts businesses in four ways: risk of reputation in the country where it pays bribes, reputation among bureaucrats as a bribe payer, risk of reputation in the company's home country, and the degradation of markets. When a business pays a bribe, it siphons off profits that could have gone to the business and shareholders, and gives company profits to government official(s) instead of shareholders. In turn, the payment of the bribe lowers the profit margin for the company in that country, and consequently lessens the incentive of the company to invest in the "bribed" country. Hellman and Kaufman (2001) found corruption systematically reduced private investment by domestic and foreign investors and created barriers to entry for small and medium sized firms.

The World Bank (2009) believes that the reason corruption is a large barrier to economic and social development is because it undermines rule of law and weakens institutional foundations that support economic development. Corruption exists in every country of the world; however, the emergence of new democracies in the former communist countries of the Soviet Union and Eastern Europe has provided an interesting opportunity to study the extent of political corruption in the former communist countries. During the 1990's the relatively rapid change from centrally planned economies to market-based economies created marked changes. A grey-market expanded to fill the ill-defined relationships in the new market-based economies.

In 2000 the Stability Pact Anti-corruption Initiative (SAPI 2005) was begun to help Eastern European countries fight corruption. The newly formed countries adopted anti-corruption laws in part because of external pressure. However, funding for the adopted programs was often inadequate and much work needed to be done to inform civil servants and get the buy-in of the business community. In 2004, the Anti-Corruption Network for Transition Economies based at the Organization for Economic Co-Operation and Development (OECD) evaluated the SPAI programs. One insight was that while the passage of laws against corruption in the countries may have progressed relatively smoothly over time, the implementation of those laws was proving to be difficult. The authors concluded that if these laws are not implemented in the near future the effectiveness of the laws to combat corruption will be severely weakened.

Some eastern European countries have made more progress toward democracy and a market economy than many of the other former communist countries (Fuxman, 1997, Moses 2000, Dabla-Norris 2006). Many former communist enterprises have stayed afloat by not paying taxes, debts, or employees, through bartering, or paying off debt with obligation notes (Moses, 2000). Kaser (2000) has estimated the loss to corruption (particularly underreported revenue and uncollected tax liability) to be half of the economic activity in the CIS states.

Hellman and Kaufman (2001) define state capture as the efforts of firms to shape the laws, policies, and regulations of the state to their own advantage by providing illicit private gains to public officials. They show that state capture is lower in countries where economic reform has been vigorously pursued compared to countries where economic reform has lagged. Hellman and Kaufman (2001) found that in higher-captor economies, captor firms annual sales growth was about three times larger than the growth rate of other firms. In low-captor economies, captor firms annual sales growth was about two-thirds the growth rate of other firms.

Libman (2006) found a negative relationship between the relative bargaining power of business and the progress of economic reforms. Bunce (1998), Goble (1999), and Moses (2000) conclude that economic reform in the former communist countries will only be successful with the simultaneous introduction of democratic reform aimed at creating a sense of community, a sense of trust, and a real rule of law. Karatnycky (2002) found whether or not a society suffered a violent revolution to be less important than the degree of civic empowerment in determining the successful outcome of the new CIS democracies. 
The purpose of this study is to examine World Bank data about corruption and the "grey" economy in the countries that comprise the former Yugoslavia. The study results can be used by non-governmental organizations (NGO), government, and regulatory officials as a basis for making policy decisions.

\section{OVERVIEW OF THE FIVE COUNTRIES/REGIONS}

Examining the characteristics of the countries/regions is a starting point to understanding their similarities and differences. The Business Environment and Economic Performance Study data used in this paper has grouped the newly formed countries as noted below. The CIA World Factbook also grouped the countries/regions in the same manner.

Table 1

Characteristics of Countries ${ }^{1}$

\begin{tabular}{|c|c|c|c|c|c|}
\hline & $\begin{array}{c}\text { Bosnia and } \\
\text { Herzegovina }\end{array}$ & Croatia & FYROM & $\begin{array}{c}\text { Serbia and } \\
\text { Montenegro }^{2}\end{array}$ & Slovenia \\
\hline $\begin{array}{l}\text { Size } \\
(\mathrm{sq} \mathrm{km})\end{array}$ & 51,197 & 56,594 & 25,713 & 91,286 & 20,273 \\
\hline Population (July 2010 est.) & $4,621,598$ & $4,486,881$ & $\begin{array}{l}2,042,000 \\
(2009)\end{array}$ & $8,011,577$ & $2,003,136$ \\
\hline Median Age & 40.3 & 41.2 & & 39.1 & 42.1 \\
\hline Urban Population & $47 \%$ & $57 \%$ & $59.3 \%$ & $56 \%$ & $48 \%$ \\
\hline $\begin{array}{l}\text { GDP real growth rate } \\
\text { (2010 est.) }\end{array}$ & $1.1 \%$ & $-1.4 \%$ & $\begin{array}{c}0.7 \% \\
(2010)\end{array}$ & $0 \%$ & $1 \%$ \\
\hline GDP per capita (2010 est.) & $\$ 6,600$ & $\$ 17,500$ & $\begin{array}{l}\$ 4,662 \\
(2009)\end{array}$ & $\$ 10,450$ & $\$ 28,400$ \\
\hline $\begin{array}{l}\text { Inflation Rate } \\
\text { (2010 est.) }\end{array}$ & $1.9 \%$ & $1.3 \%$ & $\begin{array}{c}1.6 \% \\
(2010)\end{array}$ & $4.1 \%$ & $2.1 \%$ \\
\hline $\begin{array}{l}\text { Population below poverty line (year } \\
\text { est.) }\end{array}$ & $\begin{array}{c}25 \% \\
(2004)\end{array}$ & $\begin{array}{c}17 \% \\
(2008)\end{array}$ & $\begin{array}{l}28.7 \% \\
(2008)\end{array}$ & $\begin{array}{l}7.5 \% \\
(2008)\end{array}$ & $\begin{array}{l}12.3 \% \\
(2008)\end{array}$ \\
\hline $\begin{array}{l}\text { Unemployment Rate } \\
\text { ( } 2010 \text { est.) }\end{array}$ & $27.2 \%$ & $17.6 \%$ & $\begin{array}{c}32 \% \\
(2010)\end{array}$ & $15.9 \%$ & $10.6 \%$ \\
\hline
\end{tabular}

${ }^{1}$ Source: CIA World Factbook

${ }^{2}$ Except for Size and Population, values are a simple average between the two countries

\section{THE BEEPS DATABASE}

This paper uses data from the Business Environment and Economic Performance Study (BEEPS, 2002 and BEEPS, 2005) which was developed jointly by the World Bank Institute and the European Bank for Reconstruction and Development. Managers' perceptions of areas of competition, industry concentration, firm characteristics, and economic performance are explored to understand similarities and differences between and among these countries. These important facets of firms and industries give an indication of the extent to which the economies have moved away from a controlling planned economy and toward a market system. It is expected that the countries will have differing managerial perceptions and characteristics as economic development goes forward and that economic development will be different from country to country.

Data from questions in BEEPS were analyzed using the univariate general linear model analysis of variance. By examining perception data from the five country groups and the two time periods a picture of corruption and the firms' competitive factors emerge in each country group. The five country groups share geographic proximity, and all are former members of Yugoslavia. Questions from the BEEPS study relating to firm characteristics, firm performance, and corruption and state capture were used for this study. We use the country groupings from the BEEPS database and discuss them as countries.

Result tables are presented throughout the paper. For example, if two countries have the same shading for a particular question there is no statistical difference between the results for those two countries. However, if there is 
a statistical difference between the two countries, then the results for each country have different shading. Results that have no statistical difference between countries in two different groups are colored black. Student-NewmanKeuls is the method used to determine statistical differences between countries. All statistical differences are at the 0.05 level of significance.

\section{RESULTS}

The percent of sales to government agencies in each of the countries dropped significantly between 2002 and 2005. On average sales to government agencies amounted to $22.7 \%$ of sales in 2002 but only $3.8 \%$ in 2005 . Differences across countries were not significant.

\section{DOMESTIC SALES BY CUSTOMER}

The percent of domestic sales to multinationals in the domestic market did not differ by country but did differ by year. In 2002 average sales to multinationals in the domestic market were $20.4 \%$ while in 2005 sales had dropped to $3.2 \%$.

Table 2

Customers Characteristics of Domestic Sales in 2005

\begin{tabular}{|l|c|c|c|c|c|}
\hline & $\begin{array}{c}\text { Bosnia and } \\
\text { Herzegovina }\end{array}$ & Croatia & FYROM & $\begin{array}{c}\text { Serbia and } \\
\text { Montenegro }\end{array}$ & Slovenia \\
\hline $\begin{array}{l}\text { Percentage of your domestic sales to } \\
\text { state-owned or controlled enterprises }\end{array}$ & 4.2 & 8.5 & 4.4 & 10.6 & 5.0 \\
\hline $\begin{array}{l}\text { Percentage of your domestic sales to } \\
\text { your firm's parent company or } \\
\text { affiliated subsidies }\end{array}$ & 26.2 & 4.5 & 18.4 & 20.6 & 15.9 \\
\hline $\begin{array}{l}\text { Percentage of your domestic sales to } \\
\text { large private domestic firms }\end{array}$ & 20.9 & 28.4 & 19.2 & & 31.3 \\
\hline $\begin{array}{l}\text { Percentage of your domestic sales to } \\
\text { small firms and individuals }\end{array}$ & 58.5 & 60.3 & 71.6 & 59.5 & 56.2 \\
\hline
\end{tabular}

The percent of sales to state-owned or controlled enterprises did not differ significantly between 2002 and 2005. However, there were significant country differences. Bosnia and Herzegovina, FYROM, and Slovenia had significantly lower sales to state-owned or controlled enterprises than did Croatia and Serbia and Montenegro (Table 2).

The percent of domestic sales to a firm's parent company changed significantly from 2002 to 2005 (Table 2). The average percent of sales to a parent company was $63.2 \%$ in 2002 but had dropped to $6.5 \%$ in 2005 . Significant country differences also existed. Croatian firms had 4.5 percent of their domestic sales to a parent company. This was significantly lower than the 15 to 20 percent of sales to parent firms in Slovenia, FYROM, and Serbia and Montenegro. Bosnian and Herzegovinian firms had the highest percent of sales to a parent firm of $26 \%$. (Table 2)

The percent of domestic sales to large private firms changed significantly from 2002 to 2005 . Average sales in 2002 to large private firms were $42.4 \%$ compared to average sales in 2005 that were $18.3 \%$. Significant differences between countries were apparent between FYROM and Bosnia and Herzegovina with 19-21\%, and Croatia and Slovenia with $28-31 \%$. (Table 2)

Domestic sales to small firms decreased significantly from $69.6 \%$ in 2002 to $55.6 \%$ in 2005 . FYROM had significantly higher sales to small firms and individuals (71.6\%) than firms in the other countries $(56.2-60.3 \%)$. (Table 2) 
Other data suggests that market forces have changed from 2002 to 2005. Customer characteristics in four countries were the same in 2002 and by 2005, all four countries developed additional markets for their products. Croatia in 2002 was statistically significantly different than the four other countries but in 2005, Croatia was statistically the same as the other four countries.

\section{DOMESTIC COMPETITION}

Table 3

Characteristics of Competitors

\begin{tabular}{|l|c|c|c|c|c|}
\hline & $\begin{array}{c}\text { Bosnia and } \\
\text { Herzegovina }\end{array}$ & Croatia & FYROM & $\begin{array}{c}\text { Serbia and } \\
\text { Montenegro }\end{array}$ & Slovenia \\
\hline $\begin{array}{l}\text { Exact number of your competitors in } \\
\text { the national market }\end{array}$ & 24 & 11 & & 21 & \\
\hline $\begin{array}{l}\text { Exact number of your competitors in } \\
\text { the local market }\end{array}$ & 19 & 10 & & 17 & 9 \\
\hline $\begin{array}{l}\text { Exact number of your competitors in } \\
\text { the local market 36 months ago }\end{array}$ & 17 & 8 & & 14 & 9 \\
\hline
\end{tabular}

Both year to year and country to country significant differences exist in the exact number of competitors firms face in their domestic markets. In 2002 firms from these five countries faced on average two competitors while in 2005 they faced a significantly higher 21 competitors in their domestic markets. Firms in Croatia faced 11 competitors on average a significantly lower number than the 21 to 24 faced by Serbian and Montenegrin, and Bosnian and Herzegovinian firms. (Table 3)

Firms in Croatia and Slovenia face about half the number of competitors in their local markets (9 and 10) than Serbian and Montenegrin, and Bosnian and Herzegovinian firms (17 and 19). These numbers are only slightly changed from 2002 as shown in Table 3. One might infer that perceptions of competition are restricted in Croatia and Slovenia or that competition comes from sources other than domestic/local.

CORRUPTION AND STATE CAPTURE - PUBLIC PROCUREMENT KICKBACKS AND STATE CAPTURE

Table 4

Public Procurement Kickbacks

\begin{tabular}{|l|c|c|c|c|c|}
\hline & $\begin{array}{c}\text { Bosnia and } \\
\text { Herzegovina }\end{array}$ & Croatia & FYROM & $\begin{array}{c}\text { Serbia and } \\
\text { Montenegro }\end{array}$ & Slovenia \\
\hline $\begin{array}{l}\text { Percent of the contract value would be } \\
\text { typically paid in additional or } \\
\text { unofficial payments/gifts to secure the } \\
\text { contract }\end{array}$ & .8 & .8 & 2.3 & 1.6 & .6 \\
\hline
\end{tabular}

Firms doing business with the government quite often make payments to secure the contract. From 2002 to 2005 these payments as a percent of the contract value decreased significantly from $1.5 \%$ to $1.0 \%$. Firms in Slovenia made the lowest payments as a percent of the contract value $(0.6 \%)$ to secure a government contract, just less than firms in Croatia (0.8\%) and Bosnia and Herzegovina (0.8\%). Serbian and Montenegrin firms paid significantly more $(1.6 \%)$ to obtain government contracts than firms in Slovenia, Croatia, and Bosnia and Herzegovina. Firms in FYROM paid significantly more (2.3\%) to secure a government contract as a percent of the contract value than firms in the other countries. (Table 4)

\section{STATE CAPTURE}

Hellman and Kaufman (2001) define "state capture as the efforts of firms to shape the laws, policies, and regulations of the state to their own advantage by providing illicit private gains to public officials. 
Table 5

Impact of State Capture in $2005^{3}$

\begin{tabular}{|c|c|c|c|c|c|}
\hline & $\begin{array}{c}\text { Bosnia and } \\
\text { Herzegovina }\end{array}$ & Croatia & FYROM & $\begin{array}{c}\text { Serbia and } \\
\text { Montenegro }\end{array}$ & Slovenia \\
\hline $\begin{array}{l}\text { Private payments/gifts or other } \\
\text { benefits to Parliamentarians to affect } \\
\text { their votes }\end{array}$ & 19 & & 26 & & 11 \\
\hline $\begin{array}{l}\text { Private payments/gifts or other } \\
\text { benefits to Government officials to } \\
\text { affect the content of government } \\
\text { decrees }\end{array}$ & 17 & 17 & 28 & 17 & 13 \\
\hline $\begin{array}{l}\text { Private payments/gifts or other } \\
\text { benefits to local or regional } \\
\text { government officials to affect their } \\
\text { votes or content of government } \\
\text { decrees }\end{array}$ & & & 27 & & 11 \\
\hline
\end{tabular}

${ }^{3}$ the scale for these questions is: $0=$ No impact, 25=Minor impact, 50=Moderate impact, 75=Decisive impact

Firms in Slovenia perceive the lowest impact on their business from unofficial payments or other benefits to Parliamentarians to affect their votes. Firms in FYROM perceive the most significant impact of payment to Parliamentarians compared to firms in the other countries. Bosnian and Herzegovinian firms perceive a significantly greater impact on their business than Slovenian firms but significantly less of an impact than FYROM firms. (Table 5)

When asked about the impact on their business from payments or benefits to government officials to affect the content of government decrees, firms in Slovenia, Serbia and Montenegro, Croatia, and Bosnia/Herzegovina see significantly less impact than firms in FYROM. (Table 5)

The impact from payments or benefits made to local or regional government officials to affect their votes or government decrees is least in Slovenia. Only firms in FYROM perceive a greater impact on their business. (Table 5)

\section{CORRUPTION AND STATE CAPTURE - TAX COMPLIANCE}

Table 6

Tax Compliance in 2005

\begin{tabular}{|l|c|c|c|c|c|}
\hline & $\begin{array}{c}\text { Bosnia and } \\
\text { Herzegovina }\end{array}$ & Croatia & FYROM & $\begin{array}{c}\text { Serbia and } \\
\text { Montenegro }\end{array}$ & Slovenia \\
\hline $\begin{array}{l}\text { Percent of total annual sales firms in } \\
\text { your area of business report for tax } \\
\text { purposes }\end{array}$ & 79.2 & 90.4 & 70.5 & 82.3 & 88.2 \\
\hline $\begin{array}{l}\text { Percentage of total workforce firms in } \\
\text { your area of business reports for tax } \\
\text { purposes }\end{array}$ & & 92.1 & 78.6 & 86.5 & 92.2 \\
\hline $\begin{array}{l}\text { Percentage of actual wage bill firms } \\
\text { in your area of business reports for } \\
\text { tax purposes }\end{array}$ & & 75.1 & 85.1 & 91.5 \\
\hline
\end{tabular}

Managers were asked about decisions regarding a firm's ability to comply with tax laws and regulations. From 2002 to 2005 firms reported more of their total annual sales. In 2002 firms reported about $74.8 \%$ of their total annual sales for tax purposes. In 2005 the total annual sales reported to tax authorities had increased significantly to $87.5 \%$. 
Firms in Slovenia and Croatia report the highest percent of total annual sales for tax purposes $(88.2 \%$ and 90.4\% respectively). Firms in Bosnia and Herzegovina (79.2\%), and Serbia and Montenegro (82.3\%) report significantly lower total annual sales to tax authorities than firms in Slovenia and Croatia. Firms in FYROM report the lowest percent of total annual sales (70.5\%) for tax purposes than firms in the other countries. (Table 6)

Reporting the largest percent of the total workforce for tax purposes occurs by firms in Slovenia and Croatia. Serbian and Montenegrin firms report a significantly lower percent of the total workforce than firms in Slovenia and Croatia. Firms in FYROM report the lowest percent of the total workforce than firms in the other countries. (Table 6)

Firms in Slovenia reported the highest percent of their actual wage bill (91.5\%) for tax purposes. Serbian and Montenegrin firms reported significantly less of their total wage bill $(85.1 \%)$ to tax authorities. The lowest percent of the total wage bill (75.1\%) is reported by firms in FYROM. (Table 6)

CORRUPTION AND STATE CAPTURE - UNOFFICIAL PAYMENTS

Table 7

Unofficial Payments in $\mathbf{2 0 0 5}^{4}$

\begin{tabular}{|l|c|c|c|c|c|}
\hline & $\begin{array}{c}\text { Bosnia and } \\
\text { Herzegovina }\end{array}$ & Croatia & FYROM & $\begin{array}{c}\text { Serbia and } \\
\text { Montenegro }\end{array}$ & Slovenia \\
\hline $\begin{array}{l}\text { Common for firms to pay some } \\
\text { irregular "additional payments/gifts" } \\
\text { with regard to customs, taxes, } \\
\text { licenses, regulations, services, etc. }\end{array}$ & 29.2 & 20.6 & 29.9 & 32.8 & 13.2 \\
\hline $\begin{array}{l}\text { Common for firms to know in } \\
\text { advance about how much this } \\
\text { "additional payment/gift" is to } \\
\text { officials }\end{array}$ & 28.8 & 22.0 & 29.9 & 14.4 \\
\hline $\begin{array}{l}\text { Percent of total annual sales do firm's } \\
\text { like yours typically pay in unofficial } \\
\text { payments/gifts to public officials? }\end{array}$ & .06 & & & .10 & \\
\hline
\end{tabular}

${ }^{4}$ the scale for this question is: $0=$ Never, $20=$ Seldom, $40=$ Sometimes, $60=$ Frequently, $80=$ Usually, $100=$ Always

With regards to unofficial payments to get things done with regard to customs, taxes, licenses, regulations, and services, results show no significant differences from 2002 to 2005 but significant differences between countries. Slovenia pays these unofficial payments for these services less frequently than do firms in Croatia. Firms in Bosnia and Herzegovina, FYROM, and Serbia and Montenegro pay these types of unofficial payments more frequently than firms in the other countries. (Table 7)

When asked about the likelihood of knowing in advance the amount of the additional payment to officials, there were no significant differences from 2002 to 2005. There were significant differences between countries on the advanced knowledge of the payment. Slovenian firms had less advanced knowledge of these payments compared to Croatian firms. Firms in Bosnia and Herzegovina, and Serbia and Montenegro had the most advanced knowledge of these unofficial payments. (Table 7)

The size of unofficial payments to public officials varied significantly from 2002 to 2005 . In 2002 firms paid on average almost one tenth (.09) of a percent of their annual sales to public officials, while by 2005 this number was almost half (.05) of the 2002 figure. Slovenian and Bosnian and Herzegovinian firms pay the lowest percent of their annual sales to public officials while Serbian and Montenegrin firms pay just over one-tenth of the annual sales to public officials. (Table 7) 


\section{CORRUPTION AND STATE CAPTURE - FREQUENCY OF UNOFFICIAL PAYMENTS}

Table 8

Frequency of Unofficial Payments in $2005^{5}$

\begin{tabular}{|c|c|c|c|c|c|}
\hline & $\begin{array}{c}\text { Bosnia and } \\
\text { Herzegovina }\end{array}$ & Croatia & FYROM & $\begin{array}{c}\text { Serbia and } \\
\text { Montenegro }\end{array}$ & Slovenia \\
\hline $\begin{array}{l}\text { How often would they make } \\
\text { payments/gifts to get connected to } \\
\text { and maintain public services } \\
\text { (electricity and telephone) }\end{array}$ & 18 & 8 & 10 & 23 & 4 \\
\hline $\begin{array}{l}\text { How often would they make } \\
\text { payments/gifts to obtain business } \\
\text { licenses and permits }\end{array}$ & 26 & 17 & 25 & 24 & 11 \\
\hline $\begin{array}{l}\text { How often would they make } \\
\text { payments/gifts to obtain government } \\
\text { contracts }\end{array}$ & & 17 & 23 & 28 & 9 \\
\hline $\begin{array}{lccr}\text { How often would } & \text { they } & \text { make } \\
\text { payments/gifts } & \text { to } & \text { deal } & \text { with } \\
\text { occupational health } & \text { and } & \text { safety } \\
\text { inspections } & & & \\
\end{array}$ & 29 & 14 & 22 & 28 & 7 \\
\hline $\begin{array}{l}\text { How often would they make } \\
\text { payments/gifts to deal with fire and } \\
\text { building inspections }\end{array}$ & 20 & 11 & 16 & 22 & 7 \\
\hline $\begin{array}{l}\text { How often would they make } \\
\text { payments/gifts to deal } \\
\text { environmental inspections }\end{array}$ & 15 & 9 & 11 & 17 & 5 \\
\hline $\begin{array}{l}\text { How often would they make } \\
\text { payments/gifts to deal with taxes and } \\
\text { tax collection }\end{array}$ & 29 & 11 & 17 & 23 & 5 \\
\hline $\begin{array}{l}\text { How often would they } \\
\begin{array}{l}\text { make } \\
\text { payments/gifts to } \\
\text { customs/imports }\end{array}\end{array}$ & 29 & 12 & 16 & 24 & 5 \\
\hline $\begin{array}{l}\text { How often would they make } \\
\text { payments/gifts to deal with courts }\end{array}$ & 27 & 12 & 18 & 23 & 5 \\
\hline $\begin{array}{l}\text { How often would they make } \\
\text { payments/gifts to influence the } \\
\text { content of new legislation, rules, } \\
\text { decrees, etc. }\end{array}$ & 18 & & 9 & 14 & 5 \\
\hline
\end{tabular}

${ }^{5}$ the scale for these questions is: $0=$ Never, $20=$ Seldom, $40=$ Sometimes, $60=$ Frequently, $80=$ Usually, $100=$ Always

Firms were asked about how frequently they made unofficial payments to deal with a variety of services and government offices. For payments to get connected to electricity and telephone services there were no differences from 2002 to 2005. However, there were significant differences among countries. Firms in Slovenia make these payments much less frequently than firms in Croatia or FYROM. Firms in Bosnia and Herzegovina make electrical and telephone connection payments more frequently than firms in Croatia and FYROM. Serbian and Montenegrin firms make these payments the most frequently of firms in the other countries.

Obtaining a business license or permit varies significantly between countries. Slovenian firms make unofficial payments for licenses and permits less often than firms in Croatia. Serbian and Montenegrin, FYROM, and Bosnian and Herzegovinian firms make business license and permit payments more frequently than firms in the other countries.

Unofficial payments to obtain government contracts occur less frequently in Slovenia than in the other countries. Croatian firms make these payments more frequently than Slovenian firms but less frequently than firms in FYROM. Serbian and Montenegrin firms make payments to obtain government contracts more frequently than firms in the other countries. 
Slovenian firms make payments dealing with occupational health and safety inspections less frequently than all the other countries. Croatian and FYROM firms make these occupational health and safety inspection payments more frequently than Slovenian firms. Bosnian and Herzegovinian, and Serbian and Montenegrin firms make payments for occupational health and safety inspections more frequently than firms in the other countries.

Fire and Building inspection unofficial payments occur less frequently in Slovenia than in the other countries. Croatian firms make fire and building inspection payments more frequently than Slovenian firms but less frequently than FYROM firms. Bosnian and Herzegovinian, and Serbian and Montenegrin firms make fire and building inspection unofficial payments more frequently than firms in the other countries.

Unofficial payments to deal with environmental inspections are made less frequently by Slovenian firms than firms in Croatia and FYROM. Bosnian and Herzegovinian, and Serbian and Montenegrin firms make environmental inspection payments more frequently than firms in the other countries.

Payments to deal with taxes and tax collection vary significantly from country to country. The frequency of these payments by firms in a country from least frequently to most frequently is: Slovenia, Croatia, FYROM, Serbia and Montenegro, and Bosnia and Herzegovina.

Firms making payments to deal with customs/imports occurs most frequently in Bosnia and Herzegovina. Serbian and Montenegrin firms make these payments less frequently than Bosnian and Herzegovinian firms. Firms in Croatia and FYROM make custom/import payments to officials less frequently than firms in Serbia and Montenegro. Slovenian firms make these payments less frequently than firms in other countries.

Table 9

Perceptions of the Business Environment in $2005^{6}$

\begin{tabular}{|c|c|c|c|c|c|}
\hline & $\begin{array}{c}\text { Bosnia and } \\
\text { Herzegovina }\end{array}$ & Croatia & FYROM & $\begin{array}{c}\text { Serbia and } \\
\text { Montenegro }\end{array}$ & Slovenia \\
\hline $\begin{array}{l}\text { Access to financing (e.g., collateral } \\
\text { required or financing not available } \\
\text { from banks) }\end{array}$ & 37 & 27 & 32 & 41 & 22 \\
\hline $\begin{array}{l}\text { Cost of financing (e.g., interest rates } \\
\text { and charges) }\end{array}$ & 45 & 31 & 39 & 49 & 28 \\
\hline Telecommunications & 14 & 6 & 15 & 17 & 5 \\
\hline Electricity & 17 & 6 & 17 & 17 & 5 \\
\hline Transportation & 20 & 9 & 15 & 14 & 5 \\
\hline Access to land & 14 & 7 & 15 & 13 & 12 \\
\hline Title or leasing of land & 13 & 9 & & 14 & 8 \\
\hline Tax rates & 39 & 35 & 35 & 46 & 29 \\
\hline Tax administration & & 16 & 32 & 38 & 26 \\
\hline Customs and trade regulations & 28 & 16 & 29 & 28 & 12 \\
\hline Business licensing and permits & 24 & 24 & 31 & 25 & 15 \\
\hline Labor regulations & 20 & 13 & 20 & 26 & 20 \\
\hline Uncertainty about regulatory policies & 46 & 33 & 35 & 59 & 32 \\
\hline $\begin{array}{l}\text { Macroeconomic instability (inflation, } \\
\text { exchange rate) }\end{array}$ & 38 & 37 & 38 & 51 & 27 \\
\hline Functioning of the judiciary & 36 & 39 & 37 & 35 & 26 \\
\hline Corruption & 38 & 30 & 39 & 32 & 15 \\
\hline Street crime, theft, and disorder & 28 & 13 & 27 & 20 & 8 \\
\hline Organized crime/Mafia & 29 & 14 & 29 & 18 & 6 \\
\hline $\begin{array}{l}\text { Anti-competitive practices of other } \\
\text { competitors }\end{array}$ & 38 & 36 & 38 & 37 & 27 \\
\hline $\begin{array}{l}\text { Contract violations by customers and } \\
\text { suppliers }\end{array}$ & 34 & 28 & 35 & 34 & 28 \\
\hline
\end{tabular}

${ }^{6}$ the scale for all of these questions is: $0=$ No Obstacle, $25=$ Minor Obstacle, 50=Moderate Obstacle, 75=Major Obstacle 
The five countries differed significantly on making unofficial payments or gifts to deal with courts. Slovenian firms made unofficial payments to deal with the courts less than Croatian firms. FYROM firms made payments dealing with the courts more than Croatian firms. Serbian and Montenegrin firms made payments to deal with the courts more frequently than FYROM firms. Finally, Bosnian and Herzegovinian firms made payments to deal with courts more frequently than firms in the other countries.

Payments to influence the content of new legislation, rules, decrees, etc. vary by country. Slovenian firms make these payments less frequently than firms in FYROM. Firms in FYROM make these payments less frequently than firms in Serbia and Montenegro. Bosnian and Herzegovinian firms pay to influence the content of new legislation, rules, decrees, etc. more frequently than firms in the other countries.

Firms were asked how problematic various factors were for the operation and growth of their business. Firms in Slovenia perceived access to financing as a less than minor obstacle for their business. Croatian firms feel that access to financing is a significantly greater obstacle than Slovenian firms. FYROM firms perceived access to financing as a significantly greater obstacle to their business than firms in Croatia. Bosnian and Herzegovinian firms perceive that access to financing is a significantly greater obstacle than firms in FYROM. Serbian and Montenegrin firms perceive that access to financing is the largest obstacle compared to firms in all other countries.

The cost of financing is seen as a minor obstacle by firms in Slovenia and Croatia. FYROM firms see the cost of financing as a significantly larger obstacle than Slovenian and Croatian firms. Bosnian and Herzegovinian firms perceive the cost of financing to be a greater obstacle than firms in FYROM. Serbian and Montenegrin firms perceive that the cost of financing is a moderate obstacle and greater than firms in the other countries.

Telecommunications is not perceived as an obstacle for Slovenian and Croatian firms. Firms in Bosnia and Herzegovina, FYROM, and Serbia and Montenegro see telecommunications as a significantly larger obstacle than firms in Croatia and Slovenia.

Electricity is not seen as an obstacle for firms in Slovenia and Croatia. Firms in Bosnia and Herzegovina, FYROM, and Serbia and Montenegro see electricity as a significantly larger obstacle than firms in Croatia and Slovenia.

Transportation is perceived as a small obstacle in Slovenia. Croatian firms see transportation as a significantly larger obstacle than Slovenian firms. Serbian and Montenegrin, and FYROM firms perceive transportation as significantly larger obstacle than Croatian firms. Bosnian and Herzegovinian firms perceive transportation as the largest obstacle compared to firms in the other countries.

Access to land is not seen as an obstacle by Croatian firms. Firms in Slovenia, Serbia and Montenegro, Bosnia and Herzegovina, and FYROM perceive access to land as a significantly larger obstacle than Croatian firms.

The titling and leasing of land is not seen as a large obstacle to firms in Slovenia and Croatia. Bosnian and Herzegovinian, and Serbian and Montenegrin firms see the titling and leasing of land to be a significantly greater obstacle to the growth and operation of their firm than Slovenian and Croatian firms.

Tax rates are seen as a minor obstacle to Slovenian firms. Firms in Croatia, FYROM, and Bosnia and Herzegovina see tax rates as a greater obstacle to their firms than Slovenian firms. Serbian and Montenegrin firms perceive tax rates as a significantly greater obstacle than firms in the other countries.

Tax administration is seen as almost a minor obstacle to firms in Croatia. Slovenian firms see tax administration as a greater obstacle than firms in Croatia. FYROM firms perceive tax administration as a significantly greater obstacle than firms in Slovenia. Serbian and Montenegrin firms perceive tax administration to be a significantly greater obstacle to the operation and growth of their business than firms in the other countries.

When asked if customs and trade regulations were an obstacle to the operation and growth of their firm, Slovenia firms felt that customs and trade regulations were a very small obstacle. Croatian firms perceive that 
customs and trade regulations were a significantly greater obstacle than Slovenian firms. Firms in Bosnia and Herzegovina, Serbia and Montenegro, and FYROM feel customs and trade regulations are a significantly larger obstacle than firm in Slovenia and Croatia.

Obtaining business licenses and permits is seen as a smaller obstacle to the operation and growth of businesses by Slovenian firms compared to firms in the other countries. Bosnian and Herzegovinian, Croatian, and Serbian and Montenegrin firms perceive obtaining business licenses and permits as more of an obstacle than Slovenian firms. FYROM firms see obtaining business licenses and permits to be a larger obstacle than firms in the other countries.

Croatian firms perceive labor regulations as a significantly smaller obstacle than firms in all the other countries. Slovenian, Bosnian and Herzegovinian, FYROM firms see labor regulations as a significantly greater obstacle than firms in Croatia. Serbian and Montenegrin firms perceive labor regulations as a greater obstacle than firms from the other countries.

Firms in Slovenia, Croatia, and FYROM feel that uncertainty about regulatory policies as being a minor to moderate obstacle to their businesses. Bosnian and Herzegovinian firms perceive the uncertainty about regulatory policies to be significantly greater than firms in Slovenia, Croatia, and FYROM. Serbian and Montenegrin firms feel that the uncertainty about regulatory policies is a significantly greater obstacle than firms in the other countries.

Firms in Slovenia perceive macroeconomic instability as a minor obstacle to the operation and growth of their business. Firms in Croatia, Bosnia and Herzegovina, and FYROM feel macroeconomic instability is a significantly greater obstacle than firms in Slovenia. Serbian and Montenegrin firms feel macroeconomic instability is a moderate obstacle and significantly greater than firms in the other countries.

The functioning of the judiciary is a minor obstacle to the operation and growth of their business for firms in Slovenia. Firms in Serbia and Montenegro, Bosnia and Herzegovina, FRYOM, and Croatia feel that the functioning of the judiciary is a significantly greater obstacle than firms in Slovenia.

Corruption is perceived as a small obstacle for Slovenian firms. Croatian, and Serbian and Montenegrin firms feel that corruption is a significantly greater obstacle than Slovenian firms. Bosnian and Herzegovinian, and FYROM firms feel that corruption is a significantly greater obstacle to the operation and growth of their firms than firms in the other countries.

Street crime, theft, and disorder are not seen as an obstacle to the operation and growth of a business by Slovenian firms. Croatian, and Serbian and Montenegrin firms feel that street crime, theft, and disorder are a significantly greater obstacle than Slovenian firms. Firms in FYROM and Bosnia and Herzegovina see street crime, theft, and disorder as a greater obstacle than firms in the other countries.

When asked about organized crime and the Mafia, firms in Slovenia do not feel these issues are an obstacle to the operation and growth of their business. Croatian firms believe that organized crime and the Mafia are a significantly greater obstacle than Slovenian firms. Firms in Serbia and Montenegro feel organized crime and the Mafia are a significantly greater obstacle than firms in Croatia. FYROM, and Bosnian and Herzegovinian firms perceive the obstacle presented by organized crime and the Mafia to the operation and growth of their business are larger than firms in the other countries.

Anti-competitive practices of competitors are seen as a minor obstacle by Slovenian firms. Croatian, Serbian and Montenegrin, FYROM, and Bosnian and Herzegovinian firms feel anti-competitive practices of competitors are a significantly greater obstacle than Slovenian firms.

Contract violations by customers and suppliers are a minor obstacle for Croatian and Slovenian firms. Bosnian and Herzegovinian, Serbian and Montenegrin, and FYROM firms perceive contact violations by customers and suppliers to be a significantly greater obstacle to the operation and growth of their business than firms in Croatia and Slovenia. 
Looking at the twenty factors that are problematic for the operation and growth of business by business owner and managers, the five largest obstacles are: uncertainty of regulatory policies cost of financing, macroeconomic instability, taxes rates, and anti-competitive practices by competitors. All five of these factors are seen as a moderate obstacle to the operation and growth of business by firms.

\section{CONCLUSIONS AND FURTHER STUDY}

Overall corruption in the former Yugoslavia appears to be lessening in all 5 countries. The data indicates declines in corruption and convergence in corruption (fewer differences) for all five countries.

Unofficial payments are still necessary in each country but fewer payments and lower payments to government officials are necessary in 2005 than in 2002. The data also indicates that larger payment and more frequent payments to government officials are necessary in FYROM and Serbia and Montenegro. Higher payments are necessary Serbia and Montenegro (Data not available for FYROM) for government controlled business services. The authors conclude from the unofficial payments data that state capture, from the government side, is firmly in control in these two countries.

Transparency International's Corruption Perceptions Index (CPI), a measure of corruption that uses surveys filled out by experts in each country tends to support the results of this study. In 2005 the CPI ranked Slovenia $31^{\text {st }}$ in the world on corruption. This ranking is relatively low for former communist countries. Slovenia is a member of the European Union and had to take measures against corruption to be able to join the EU. The other countries of the former Yugoslavia are not EU member but, rather are EU wannabes. The CPI for the other countries is: Croatia tied 67, Bosnia/Herzegovina tied 82, and FYROM and Serbia/Montenegro tied 97.

A limitation of this corruption study is that the study covers a limited range of companies, businesses and issues in the corruption arena. Business owners/managers responded in the BEEPS study to questions regarding their business activities. Other data sources indicate that corruption occurs in many fields of endeavor. As an example, it has been reported that the highest percent of bribery payments are made to doctors and nurses, a type of business not covered by the BEEPS studies.

Extension of the current study would be to look at the BEEPS data for 2008 and 20011 . The 2008 BEEPS data were released in mid-2011, and the 2011 BEEPS data will probably be released in 2014 or 2015.

\section{AUTHOR INFORMATION}

Frank H. Wadsworth, Ph.D., CFE, is the Division Head and Professor of Marketing and International Studies in the Division of Business at Indiana University Purdue University Columbus. Frank has taught in the Executive MBA program at the Hanoi School of Business, Vietnam National University and the MBA program at De La Salle University, Dasmarinus, Philippines. Frank has conducted research for the U.S. Federal Trade Commission, International Franchise Association, American Franchisee Association, international franchise systems, and many local and regional businesses. E-mail: fwadswo@iupuc.edu. Corresponding author.

Jerry E. Wheat is Professor Emeritus of Business Administration at Indiana University Southeast (IUS) and Dean Emeritus of the School of Business at IUS. He has taught Business Ethics and International Business in eight other countries besides the U.S. and is a Fulbright Scholar. His most recent teaching experience was at the Hanoi School of Business where he taught entrepreneurship. Dr. Wheat's research interests include transition economies and entrepreneurship education for post-communist societies. E-mail: jwheat@ius.edu

Brenda Swartz is Director of the Regional Economic Development Resource Center and Adjunct Lecturer in Economics at Indiana University Southeast. She initiated area CEO Roundtables and has organized entrepreneur training for profit and for non-profit entities. She has developed the Youth/Adult Mentor Entrepreneur program which works with teens to help them take steps toward a career path. Swartz has done economic development work for the U.S. State Department in Russia and Ukraine. She has reviewed economic development proposals in Bucharest for the Romanian government. Swartz has a B.S. from Indiana University Bloomington and an M.B.A from the University of Louisville. E-mail: bswartz@ius.edu 


\section{REFERENCES}

1. BEEPS 2002, Business Environment and Enterprise Performance Survey, Conducted by the European Bank for Reconstruction and Development and the World Bank, located at: http://www.ebrd.com/pages/research/analysis/surveys/beeps.shtml.

2. BEEPS 2005, Business Environment and Enterprise Performance Survey, Conducted by the European Bank for Reconstruction and Development and the World Bank, located at: http://www.ebrd.com/pages/research/analysis/surveys/beeps.shtml.

3. Bunce, Valerie (1998), "Regional Differences in Democratization: The East versus the South," Post-Soviet Affairs, Vol. 14, No. 3, 187-211.

4. Dabla-Norris, Era, (2006), "The Challenge of Fiscal Decentralisation in Transition Countries," Comparative Economic Studies, Vol. 48, 100-131.

5. $\quad$ Fuxman, Leonaor (1997), "Ethical Dilemmas of Doing Business in Post-Soviet Ukraine," Journal of Business Ethics, Vol. 16 (September), 1273-1282.

6. Goble, P. (1999), “End Note: Where Reforms Trump Resources,” Radio Free Europe/Radio Liberty Newsline at: www.refrl.org/newsline.

7. Hellman, Joel and David Kaufman (2001), "Confronting the Challenge of State Capture in Transition Economies," Finance and Development, Vol. 38, No. 3 at http://www.imf.org/external/pubs/ft/fandd/2001/09/hellman.htm.

8. Karatnycky, Adrian (2002), "Making Democratization Work," Harvard International Review, Vol. 24, No. 2 (Summer), 50-54.

9. Kaser, Michael (2000), “A 15-year U-curve for the Former Soviet Economies?,” European Business Journal, Vol. 12, No. 3, 158-165.

10. Libman, Alexander (2006), "Government-Business Relations and Catching Up Reforms in the CIS," The European Journal of Comparative Economics, Vol. 3, No. 2, 263-288.

11. Moses, Joel C. (2000), "Policy Dilemmas of Post-Soviet Countries," Policy Studies Journal, Vol. 28, No. 1, 29-45.

12. Nichols, Philip M. (2000), "Dealing with an Eruption of Corruption," Financial Times, May 30, 2000, 15.

13. Stability Pact Anti-Corruption Initiative (2005), "International Cooperation to Fight Corruption in South Eastern Europe: Achievements, lessons learned and future challenges." Paper was commissioned by the Anti-Corruption Network for Transition Economies based at the Organization for Economic Co-operation and Development. It was prepared by the Basel Institute on Governance in February 2005 with support from the Swiss Agency for Development and Cooperation. Located at: http://www.oecd.org/dataoecd/49/32/37152800.pdf

14. Transparency International, "Global Corruption Report, 2006," www.transparency.org.

15. Wolfensohn, James (1996), Statement by President of the World Bank, Beyond Transition Newsletter, Vol. 7, Issue 9-10, September/October, 9.

16. World Bank (2009), "Anticorruption Overview," www.worldbank.org. 
NOTES 